\title{
Response of NPK and Sulphur on Nutrient Analysis and quality attributes of Cauliflower (Brassica oleracea var. botrytis L.)
}

\author{
Premraj Gocher, A.K. Soni, Arun Kumar Mahawar*, S.P. Singh and Sunita Koodi \\ Department of Horticulture, S. K. N. College of Agriculture (SKNAU), Jobner, Jaipur \\ (Rajasthan) - 303329, India \\ *Corresponding author
}

\section{A B S T R A C T}

A field experiment was conducted at Horticulture Farm, S.K.N. College of

\begin{tabular}{|l|}
\hline Ke y w or d s \\
Cauliflower, \\
$\begin{array}{l}\text { NPKS content in } \\
\text { soil and curd, } \\
\text { Nutrient analysis. }\end{array}$ \\
\hline Article Info \\
\hline $\begin{array}{l}\text { Accepted: } \\
\text { 30 June } 2017 \\
\text { Available Online: } \\
\text { 10 July } 2017\end{array}$ \\
\hline
\end{tabular}
Agriculture, Jobner (Jaipur) during Rabi season 2015-16. The experiment consisting four levels of NPK $(0,75,100$ and $125 \%$ RD of NPK) and four doses of sulphur $\left(0,20,40\right.$ and $60 \mathrm{~kg}$ sulphur ha $\left.{ }^{-1}\right)$. The total 16 treatment combinations were tested in randomized block design with three replications. Results revealed that application of 125 per cent recommended dose of NPK and sulphur doses @ $60 \mathrm{~kg} \mathrm{ha}^{-1}$ to the cauliflower crop significantly increased the nitrogen, phosphorus, potassium and sulphur content in curd and nitrogen, phosphorus, potessium in soil as compared to control, 75 per cent recommended dose of NPK and $20 \mathrm{~kg}$ sulphur $\mathrm{ha}^{-1}$ but statistically at par with 100 per cent recommended dose of NPK and $40 \mathrm{~kg}$ sulphur ha ${ }^{-1}$. The combined application of 100 per cent recommended dose of NPK with $40 \mathrm{~kg}$ sulphur ha ${ }^{-1}$ proved to be most superior treatment combination in terms of nutrient analysis because resulting saving of 25 per cent recommended dose of NPK and $20 \mathrm{~kg}$ sulphur ha ${ }^{-1}$.

\section{Introduction}

Cauliflower (Brassica oleracea var. botryitis L.) is the most popular vegetable crop among cole crops belong to the family Cruciferae. It is being grown round the year for its white and tender curd. It is a fair source of vitaminA $(51 \mathrm{IU})$, vitamin-C $(56 \mathrm{mg})$, riboflavin $(0.10 \mathrm{mg})$, thiamin $(0.04 \mathrm{mg})$, nicotinic acid (1.0 mg), calcium $(33 \mathrm{mg})$, phosphorus $(57$ $\mathrm{mg}$ ), potassium (138 mg), moisture (90.8 g), carbohydrates $(4.0 \mathrm{~g})$, protein $(2.6 \mathrm{~g})$, fat $(0.4$ $\mathrm{g})$, fiber $(1.2 \mathrm{~g})$, and iron $(1.5 \mathrm{mg})$ per $100 \mathrm{~g}$ of edible portion of cauliflower (Fageria $e t$ al., 2012). Cauliflower is grown commercially on an area of about 433.9 thousand hectares with an annual production of about 85.73 lakh tonnes and productivity is about 19.8 MT/ha In India, West Bengal have maximum area, production and productivity. Total area of cauliflower in Rajasthan is about 9.42 thousand ha with an annual production of about 36.61 thousand tonnes and productivity about 3.89 MT (Anonymous, 2014).

Nitrogen is an essential plant nutrient, which is involved in physiological processes and enzyme activities. Farmers use urea excessively as a nitrogen fertilizer to enhance 
curd initiation and increase curd size in cauliflower. Nitrogen could increase production of cauliflower, but the curd quality is affected. High nitrogen contents with deficits of other nutrients could reduce the storage life of cauliflower and buttoning (Kirthisinghe, 2006). Mineral nutrition does play an important role in influencing the quality of crops and it is fact that the soil health deteriorates due to continuous use of chemical fertilizers (Savci, 2012). Phosphorus is a constituent of nucleic acid, phytin and phosphorus. It is also an essential constituent of majority of enzymes which are of great important in the transformation of energy in carbohydrate and fat metabolism and also in respiration in plants. Potassium imparts increased vigour and disease resistance to plant. It also regulates water conduction within the plant cell and water loss from the plant by maintaining the balance between anabolism, respiration and transpiration. Thus reduces tendency to wilt and help in better utilization of available water which ultimately help in the formation of protein and chlorophyll and quality (Rutkauskiene and Poderys, 1999). Sulphur plays a vital role in biosynthesis of certain amino acids (cysteine, cystine and methionine) that are essential component of protein and also help in the synthesis of coenzyme-A and formation of chlorophyll and nitrogenase enzyme. Further, sulphur also provides winter hardiness and drought tolerance, control of insect pests and disease etc. Two natural growth regulators, thiamin and biotin contain sulphur. Sulphur occurs in glutathione that is important in oxidation reduction reaction. It is one of the constituents of vitamin $\mathrm{B}_{1}$, some volatile oils and amino acids like methinine $(21 \% \mathrm{~S})$. It is involved in various metabolic and enzymatic processes in the plant (Goswami, 1988). The substantial decrease in $\mathrm{SO}_{2}$ emission to less than $10 \mathrm{~kg} \mathrm{ha}^{-1}$ of $\mathrm{S}$ further intensified $\mathrm{S}$ deficiency in plants, because as much as 30 per cent of its total amount can be absorbed from $\mathrm{SO}_{2}$ in the air. After reduction in the plant $S$ participates in various primary and secondary compounds, such as the amino acids cysteine and methionine, vitamins $B_{1}$ and $\mathrm{H}$ and enzymes and coenzymes (Haneklaus et al., 1997).

\section{Materials and Methods}

The field experiment was conducted at Horticulture farm, S.K.N. College of Agriculture, Jobner, Jaipur during Rabi season 2015-16 during October to January. The mean daily temperature maximum and minimum during the growing season of cauliflower fluctuated $37.2^{\circ} \mathrm{C}$ and $2.1^{\circ} \mathrm{C}$, relative humidity ranged from 41 to 67 per cent. The mean value of evaporation from USWB class pan ranged from 1.9 to $5.9 \mathrm{~mm}$. There was a total rainfall of $10.0 \mathrm{~mm}$ in $\mathrm{Rabi}$ season as against the average rainfall 400 $\mathrm{mm}$. The soil was loamy sand in texture, slightly alkaline in reaction, poor in organic carbon with low available nitrogen, phosphorus and medium in potassium content.

The experiment was comprised of 16 treatment combinations carried out in Randomized Block Design (RBD) with four levels of NPK $(0,75,100$ and $125 \%$ RD of NPK) denoted by $F_{0}, F_{1}, F_{2}$ and $F_{3}$ and Sulphur (0, 20, 40 and $\left.60 \mathrm{~kg} \mathrm{ha}^{-1}\right)$ denoted by $\mathrm{S}_{0}, \mathrm{~S}_{1}, \mathrm{~S}_{2}$ and $\mathrm{S}_{3}$. The recommended dose of NPK for cauliflower is $120 \mathrm{~kg}, 80 \mathrm{~kg}$ and 80 $\mathrm{kg}$ per ha respectively. Full dose of $\mathrm{P}_{2} \mathrm{O}_{5}, \mathrm{~K}_{2} \mathrm{O}$ and half dose of $\mathrm{N}$ in various treatments were applied manually as the basal dose at the time of transplanting. Remaining dose of nitrogen was given as top dressing in two split doses at 30 and 45 days after transplanting. Sulphur was applied as per treatment through agriculture grade elemental sulphur and was broadcasted uniformly before transplanting and incorporated in the soil. Seeds of cauliflower $c v$. Pusa Synthetic obtained from 
National Seed Corporation treated with 0.02 per cent Thiram to save the seedlings from damping off disease. The seedlings were ready for transplanting in 4-5 weeks.

\section{Total chlorophyll content in leaves $(\mathrm{mg} / \mathrm{g})$}

Total chlorophyll content was determined at 40 DAT by using the method of Arnon, 1949. $50 \mathrm{mg}$ fresh leaf material was used for chlorophyll estimation. The materials were homogenized with $5 \mathrm{ml}$ of 80 per cent acetone in a mortar with pestle. Then this aliquot was taken and centrifuged for 10 minutes at 2000 $\mathrm{rpm}$ and made the final volume to $10 \mathrm{ml}$ and clear supernatant solution was taken. Absorbance of clear supernatant was measured at $663 \mathrm{~nm}$ and $645 \mathrm{~nm}$ on Spectronic-20 (spectrophotometer).

$20.5(\mathrm{~A} 645+8.02(\mathrm{~A} 663)$
Total chlorophyll $(\mathrm{mg} / \mathrm{g})=$----------- X V
$1000 \mathrm{X} \mathrm{W}$

Where,

$A=$ Absorbance specific wave lengths

$\mathrm{V}=$ Final volume of chlorophyll extract in $80 \%$ acetone solution

$\mathrm{W}=$ Fresh weight of bits of leaves extracted

\section{Results and Discussion}

\section{Effect of NPKs on nutrient analysis}

The application of different levels of NPK significantly influenced the NPKs content in curd (Table 2). The mean maximum nitrogen (3.46\%), phosphorus $(0.309 \%)$, potassium $(2.87 \%)$ and sulphur $(1.27 \%)$ content in curd were recorded under 125 per cent recommended dose of NPK $\left(\mathrm{F}_{3}\right)$, which was significantly superior to $\mathrm{F}_{0}$ and $\mathrm{F}_{1}$ but statistically at par with $F_{2}$. Whereas, minimum nitrogen (2.33\%), phosphorus $(0.204 \%)$, potassium $(2.10 \%)$ and sulphur $(1.00 \%)$ content in curd were observed under control. The application of different levels of NPK also significantly influenced the NPKs content in soil. The mean maximum nitrogen (137.92 kg/ha), phosphorus (18.52 $\mathrm{kg} \mathrm{ha}^{-1}$ ) and potassium $\left(142.53 \mathrm{~kg} \mathrm{ha}^{-1}\right)$ in soil were recorded under 125 per cent recommended dose of NPK $\left(\mathrm{F}_{3}\right)$, which was significantly superior to $F_{0}$ and $F_{1}$ but statistically at par with 100 per cent recommended dose of NPK $\left(\mathrm{F}_{2}\right)$. Whereas, minimum nitrogen (131.78 $\mathrm{kg} / \mathrm{ha})$, phosphorus (16.38 $\left.\mathrm{kg} \mathrm{ha} \mathrm{ha}^{-1}\right)$ and potassium $\left(128.71 \mathrm{~kg} \mathrm{ha}^{-1}\right)$ content in soil was recorded under control, respectively. The results of present investigation revealed that NPK, Sulphur and chlorophyll content in curd increased significantly with the increasing levels of NPK (Table 2). The content of any nutrient in the plant is directly related to its availability in the feeding zone and the growth of the plant. It is obvious that the application of 100 per cent recommended dose of NPK increased the concentration of NPK in soil and plant. Markovic and Diurovaka (1990) reported that proper nitrogen dose, improve nutritional value of cauliflower and reduces the chances of buttoning. However potassium helps in the formation of protein and chlorophyll and improves the quality of cabbage head in relation to taste and keeping quality. Kumhar (2004), Haque et al., (2006) and Abd el-All and EL- Shabrawy (2013) (Table 1).

\section{Effect of NPKs on quality attributes}

Chlorophyll content (Table 2) of cauliflower also significantly influenced by different fertility levels. The maximum chlorophyll content $\left(1.42 \mathrm{mg} \mathrm{g}^{-1}\right)$ was recorded under $\mathrm{F}_{3}$ (125 per cent recommended dose of NPK), which was found to be significantly higher over $F_{0}$ and $F_{1}$ but it was statistically at par with $F_{2}$. The NPK are considered as one of 
the major nutrient required for proper growth and development of the plant. Besides this, nitrogen is a main constituent of protoplasm, cell nucleus, amino acids, proteins, chlorophyll and many other metabolic products (Kumhar, 2004). Phosphorus is a constituent of nucleic acid, phytin and phospholipids.

The response to potassium fertilization in terms of overall improvement in growth parameters in further supported by the fact that the leaching losses of potassium were more in light textured soils. Therefore, potassium fertilization improved overall crop growth in terms of plant height, number of leaves per plant and quality attributes viz. chlorophyll content in leaves. Potassium helps in the protein and chlorophyll formation ultimately the NPK are used for better vegetative growth. The results are close conformity with the finding of Patil et al., (2003), Kumhar (2004), and Abd el-All and EL- Shabrawy (2013).

\section{Effect of sulphur on nutrient analysis}

The perusal of data presented in table 2 shows that the NPKs content of curd was influenced by different sulphur doses. The maximum nitrogen (3.47 \%), phosphorus $(0.311 \%)$, potassium (2.86 \%) and sulphur (1.26\%) content were recorded under the treatment 60 $\mathrm{kg} \mathrm{S} \mathrm{ha}{ }^{-1}\left(\mathrm{~S}_{3}\right)$. While, minimum nitrogen (2.33 $\%)$, phosphorus $(0.202 \%)$, potassium $(2.08$ $\%)$ and sulphur

(1.01\%) content in curd were recorded in control. The treatment $S_{2}$ was found significantly superior over control and $S_{1}$ but statistically at par with $S_{3}$ was recorded. Results in same table also show that the NPKs content in soil was influenced by different sulphur doses. The maximum nitrogen (137.48 kg ha ${ }^{-1}$ ), phosphorus (18.61 kg ha ${ }^{-1}$ ) and potassium (143.11 $\mathrm{kg} \mathrm{ha}^{-1}$ ) content in soil were recorded under the treatment $60 \mathrm{~kg} \mathrm{~S}^{-}$ ${ }^{1}\left(\mathrm{~S}_{3}\right)$. While, minimum nitrogen $(132.12 \mathrm{~kg}$ $\left.\mathrm{ha}^{-1}\right)$, phosphorus $\left(16.25 \mathrm{~kg} \mathrm{ha}{ }^{-1}\right)$ and potassium $\left(128.11 \mathrm{~kg} \mathrm{ha}^{-1}\right)$ content in soil were in control.

The treatment $S_{2}$ was found significantly superior over control and $S_{1}$ but statistically at par with $\mathrm{S}_{3}$. Increased accumulation of nutrients especially $\mathrm{N}, \mathrm{P}$ and $\mathrm{S}$ in vegetative plant parts concomitant with improved metabolism led to greater translocation of these nutrients to reproductive structure of crops. The results are in conformity with the findings of Chhipa (2005) and Abd el-All and EL- Shabrawy (2013).

Table.1 Nutrients analysis with their estimating methods

\begin{tabular}{ll}
\hline Nutrient content & Estimating methods \\
\hline N content in curd (\%) & $\begin{array}{l}\text { Nesselar's reagent in spectrophotometer method (Snell and } \\
\text { Snell, 1949). }\end{array}$ \\
P content in curd (\%) & $\begin{array}{l}\text { Spectrophotometer method using Triacid Ammonium } \\
\text { Molybdate-Ammonium Vabnadete solution (Jackson, }\end{array}$ \\
& 1973). \\
K content in curd (\%) & Flame photometer method including Triacid, Potassium \\
& standard solution (Richards, 1954). \\
Sulphur content in curd (\%) & Turbidometric method (Tabutabi and Bermner, 1970). \\
Available $\mathrm{N}(\mathrm{kg} / \mathrm{ha})$ in soil & Alkaline permanganate method (Subbiah and Asija, 1956). \\
Available $\mathrm{P}_{2} \mathrm{O} 5(\mathrm{~kg} / \mathrm{ha})$ in soil & Olsen's method (Olsen et al., 1954). \\
Available $\mathrm{K}_{2} \mathrm{O}(\mathrm{kg} / \mathrm{ha})$ in soil & Flame photometer method (Metson, 1956). \\
\hline
\end{tabular}


Table.2 Effect of NPK and sulphur on nutrient analysis and quality attributes of Cauliflower

\begin{tabular}{|c|c|c|c|c|c|c|c|c|}
\hline Treatments & $\begin{array}{c}\text { N content } \\
(\mathrm{kg} / \mathrm{ha})\end{array}$ & $\begin{array}{c}P \text { content } \\
(\mathbf{k g} / \mathrm{ha})\end{array}$ & $\begin{array}{c}\text { K content } \\
(\mathbf{k g} / \mathbf{h a})\end{array}$ & $\begin{array}{c}\text { S content } \\
(\mathbf{k g} / \mathbf{h a})\end{array}$ & $\begin{array}{c}\text { Available } \\
\text { N }\end{array}$ & $\begin{array}{c}\text { Available } \\
\qquad \mathbf{P}_{2} \mathbf{O}_{5}\end{array}$ & $\begin{array}{c}\text { Available } \\
\qquad \mathrm{K}_{2} \mathrm{O}\end{array}$ & $\begin{array}{c}\text { Chlorophyll } \\
\text { content } \\
(\mathrm{mg} / \mathrm{g})\end{array}$ \\
\hline \multicolumn{9}{|l|}{ Fertility levels } \\
\hline Control $\left(\mathrm{F}_{0}\right)$ & 2.33 & 0.204 & 2.10 & 1.00 & 131.78 & 16.38 & 128.71 & 1.09 \\
\hline 75 per cent RD of NPK $\left(F_{1}\right)$ & 3.13 & 0.266 & 2.52 & 1.13 & 133.23 & 17.67 & 135.80 & 1.26 \\
\hline 100 per cent RD of NPK $\left(F_{2}\right)$ & 3.44 & 0.296 & 2.80 & 1.24 & 136.19 & 18.49 & 141.69 & 1.37 \\
\hline 125 per cent RD of NPK $\left(F_{3}\right)$ & 3.46 & 0.309 & 2.87 & 1.27 & 137.92 & 18.52 & 142.53 & 1.42 \\
\hline SEm \pm & 0.03 & 0.005 & 0.03 & 0.01 & 1.23 & 0.26 & 2.02 & 0.04 \\
\hline CD at $5 \%$ & 0.09 & 0.014 & 0.09 & 0.04 & 3.54 & 0.76 & 5.82 & 0.11 \\
\hline \multicolumn{9}{|l|}{ Sulphur levels (kg/ha) } \\
\hline Control $\left(\mathrm{S}_{0}\right)$ & 2.33 & 0.202 & 2.08 & 1.01 & 132.12 & 16.25 & 128.11 & 1.05 \\
\hline Sulphur $20 \mathrm{~kg} \mathrm{ha}^{-1}\left(\mathrm{~S}_{1}\right)$ & 3.11 & 0.265 & 2.55 & 1.14 & 133.58 & 17.66 & 135.45 & 1.25 \\
\hline Sulphur $40 \mathrm{~kg} \mathrm{ha}^{-1}\left(\mathrm{~S}_{2}\right)$ & 3.46 & 0.298 & 2.79 & 1.23 & 135.95 & 18.55 & 142.05 & 1.38 \\
\hline Sulphur $60 \mathrm{~kg} \mathrm{ha}^{-1}\left(\mathrm{~S}_{3}\right)$ & 3.47 & 0.311 & 2.86 & 1.26 & 137.48 & 18.61 & 143.11 & 1.46 \\
\hline $\mathrm{SEm} \pm$ & 0.03 & 0.005 & 0.03 & 0.01 & 1.23 & 0.26 & 2.02 & 0.04 \\
\hline CD at $5 \%$ & 0.09 & 0.014 & 0.09 & 0.04 & 3.54 & 0.76 & 5.82 & 0.11 \\
\hline
\end{tabular}


Fig.1 Effect of NPK and sulphur on NPKS content in curd

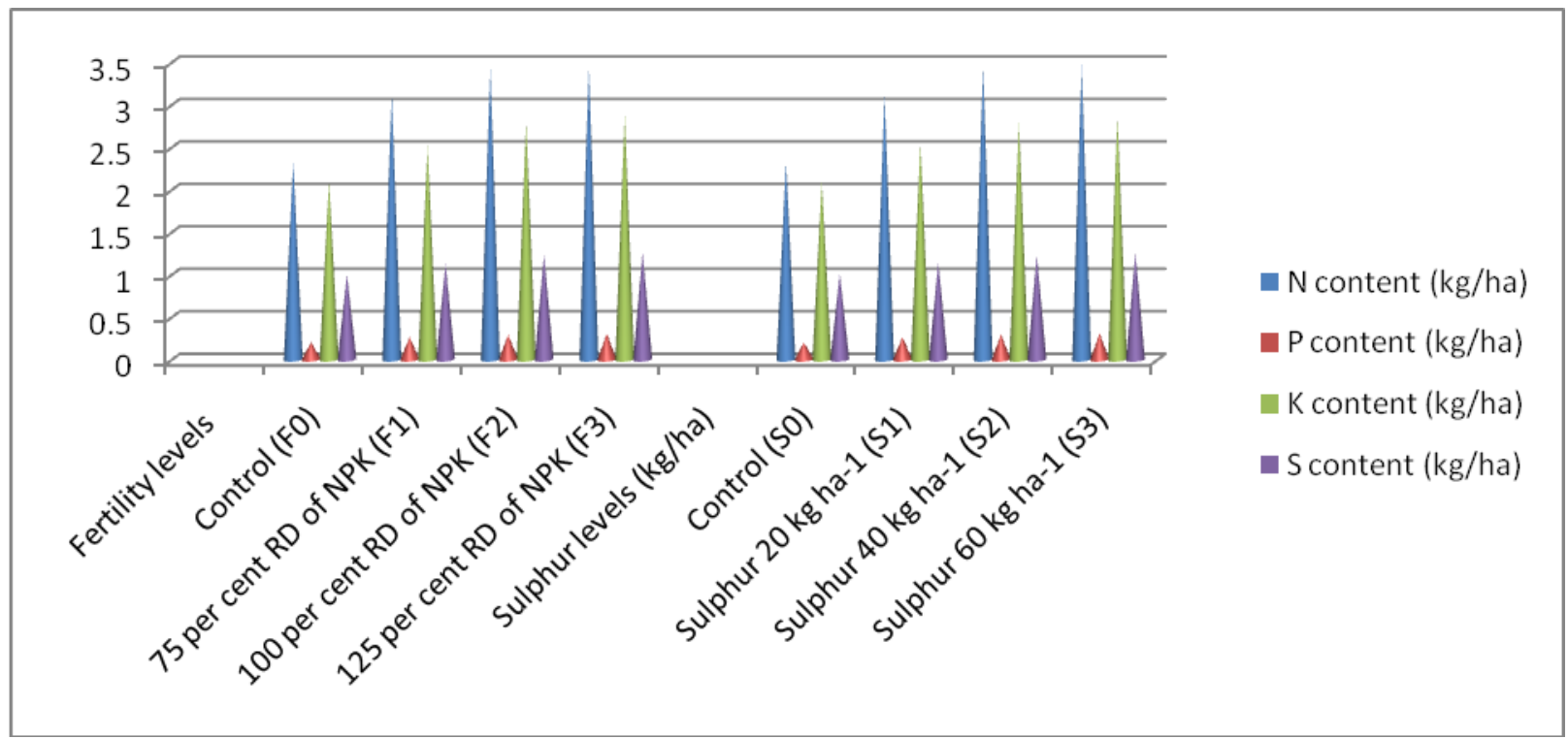

From the experiment, NPK and sulphur increased significantly with the increasing levels of sulphur (Table 2 and Fig. 1). The results may be due to the fact that nitrogen and sulphur are the main ingredients of protein and increase in their availability increase the utilization of nitrogen for the synthesis of protein. Sulphur synthesized some sulphur containing amino acids like cysteine and methionine and resulted in increased protein content, which is in accordance with the findings of Hunashikatti et al., (2000a), Gautam (2012) and Verma and Nawange (2015). Increasing of the rate of applied sulphur from 20,40 and $60 \mathrm{~kg} \mathrm{~S} h a^{-1}$ significantly increased $\mathrm{N}, \mathrm{P}, \mathrm{K}$ and $\mathrm{S}$ contents of cauliflower curd. These results are in agreement with those reported by Bhagavatagoudra and Rokhade (2001).

\section{Effect of sulphur on quality attributes}

Application of different sulphur doses had significant effect on chlorophyll content of leaves (Table 2). The maximum value of chlorophyll (1.46 $\mathrm{mg} \mathrm{g}^{-1}$ ) content was recorded with $60 \mathrm{~kg} \mathrm{~S} \mathrm{ha}^{-1}$ which was statistically at par with $40 \mathrm{~kg} \mathrm{~S} \mathrm{ha}^{-1}$. The minimum chlorophyll content of leaves was recorded in $\mathrm{S}_{0}$ (control).The mean increase in chlorophyll content of leaves under $\mathrm{S}_{2}$ treatment was found to be 31.43 and 10.40 per cent over $S_{0}$ and $S_{1}$, respectively. Application of sulphur has been reported to help in lowering soil $\mathrm{pH}$ resulting in increased availability of several nutrients or might be due to the activation of a number of enzymes, energy transformation, chlorophyll formation and also in carbohydrate metabolism (Tandon, 1986), Due to sulphur fertilization, xylem and collenchymas fiber are also reported to be thickened resulting into more pronounced growth of plant. Increasing vegetative growth of cauliflower due to sulphur fertilization in the present investigation are in close conformity with the finding of Meena (2004) and Bhagavatagoudra and Rokhade (2001). Sulphur also plays an important role in the production of chlorophyll. It was found that the sulphur increased the chemical and biological activation of iron in the leaves resulting in increased chlorophyll content (Chhipa, 2005).

On the basis of present investigation, it can be concluded that the combined application of 100 per cent recommended dose of NPK 
along with sulphur $40 \mathrm{~kg} \mathrm{ha}^{-1}$ was found best to harvest a good cauliflower crop with maximum nutrient content in curd as well as improving the soil condition by providing more nutrients, respectively because resulting saving of 25 per cent recommended dose of NPK and $20 \mathrm{~kg}$ sulphur $\mathrm{ha}^{-1}$. Thus, application of 100 per cent recommended dose of NPK along with sulphur $40 \mathrm{~kg} \mathrm{ha}^{-1}$ recommended for cauliflower crop.

\section{References}

Abd el-All, H.M. and EL- Shabrawy, R.A. 2013. Effect of some phosphorus sources, nitrogen and sulphur levels on yield, quality, sulforaphane and Vit. C content in broccoli. Research Journal of Agriculture and Biological Sciences, 9 (6): 351-365.

Anonymous, 2014. Indian Horticulture Database. Ministry of Agriculture, Government of India, Gurgaon (Haryana).

Arnon, D.I. 1949. Copper enzymes in isolated chloroplast- polyphenol oxidase in Beta- vulgaris. Plant Physiology, 24: 115.

Bhagavatagoudra, K.H. and Rokhade, A.K. 2001. Effect of sources and levels of sulphur nutrition on growth and yield of cabbage. Karnataka Journal of Agricultural Science, 14 (3): 724-726.

Chhipa, B.G. 2005. Effect of different levels of sulphur and zinc on growth and yield of cauliflower (Brassica oleracea var. botrytis L.). Thesis M.Sc. (Ag.) submitted to RAU, Bikaner campus, Jobner.

Fageria, M.S., Choudhary, B.R. and Dhaka, R.S. 2012. Vegetable Crops Production Technology, Volume-II. Kalyani Publication, Noida (UP).

Gautam, P. 2012. Response of knol-khol (Brassica oleracea var. caulorapa) to organic manures and inorganic fertilizers. Thesis submitted to SKRAU, Bikaner.

Goswami, N.N. 1988. Sulphur in Indian Agriculture. The Fertilizer Association, New Delhi, India.

Haneklaus, S., Hoppe, L., Bahadir, M. and Schnug, E. 1997. Sulphur nutrition and alliin concentrations in Allium species. Molecular, ecophysiological and nutritional aspects. Leiden, Backhuys Publishers, pp 367.

Haque, K.M.F., Jahangir, A.A., Haque, M.E., Mondal, R.K., Jahan, M.A.A. and Sarker, M.A.M. 2006. Yield and nutritional quality of cabbage as affected by nitrogen and phosphorus fertilization. Bangladesh Journal of Scientific and Industrial Research, 41 (1-2): 41-46.

Hunashikatti, M.H., Channal, H.T., Sarangamath, P.A., Manjunathaiah, H.M. and Hebsur, N.S. 2000a. Effect of sulphur and molybdenum on the dry matter yield and uptake of S and Mo by cabbage. Karnataka Journal of Agricultural Science, 13 (4): 840-845.

Jackson, M.L., 1973. Soil Chemical Analysis. Prentice Hall of India Pvt. Ltd., New Delhi.

Kirthisinghe, J. P. 2006. A complete and balanced fertilizer recommendation based on a systemic approach for cauliflower (Brassica oleracea var. Botrytis L). Post graduate Institute of Agriculture, University of Peradeniya. Sri Lanka.

Kumhar, R. 2004. Effect of NPK and vermicompost on growth, yield and quality of cauliflower (Brassica oleracea var. botrytis Lamk.) CV Pusa Katki. M.Sc. (Ag.) Thesis submitted to Rajasthan Agriculture University, Bikaner, Campus-Jobner.

Markovic, V. and Diurovaka, M. 1990. The effect of mineral nutrition on the yield and quality of cauliflower (Brassica 
oleracea var. botryitis L.). Acta Horticulture, 267: 101- 109.

Meena P.S. 2004. Effect of nitrogen and sulphur on growth and yield of sprouting broccoli (Brassica oleracea var. italica L.) cv. EU-Green. Udyanika, 10 (3): 7-10.

Metson, A.J. 1956. Methods of chemical analysis for soil survey samples. Bull no. 2, Deptt. Science Md. Research Soil Bureau 12.

Olsen, S.R., Cole, V.C., Watanable, F.S. and Dean, L.A., 1954. Estimation of available phoshphorus in soil by extraction with sodium bicarbonate. Cir. V.S. Deptt. Agric., pp. 939.

Patil, B. N.; Ingle, V. G.; Patil, S. S., 2003. Effect of spacings and nitrogen levels on growth and yield of knol-khol (Brassica oleracea var. caulorapa) cv. White Vienna. Annals of Plant Physiology, 17 (2): 110-113.

Richards, L.A., 1954. Diagnosis and improvement of saline soil and alkaline soils. U.S.D.A. Handbook No.60.

Rutkauskiene, G. and Poderys, M. 1999. Influence of NPK fertilizers on the yield and quality of white cabbage heads.
Sodininkyste ir darzininkyste, 18: 155162.

Savci, S. 2012. An Agricultural Pollutant: chemical fertilizer, International Journal Environmental Science and Development, 3 (1): 77- 80.

Snell, P.D. and Snell, G.T. 1949. "Colorimetric methods of analysis". 3rd Edn. Volume II, D Van. Nastrand Inc., New York.

Subbiah, B.V. and Ashija, G.L., 1956. A rapid procedure for determination of available $\mathrm{N}$ in soil. Current Science, 25: 259-60.

Tabutabi, M.A. and Bermner, J.M. 1970. A terbitometric method of determining sulphur in plant materials. Agronomy Journal, 62: 806-808.

Tandon, H.L.S. 1986. Fertilizer recommendation for horticultural crops in India. A Guide Book F.D. Co., New Delhi, pp. 112.

Verma, H. and Nawange, D.D. 2015. Effect of different levels of nitrogen and Sulphur on the growth, Yield and quality of cabbage [Brassica oleracea var. capitata L.]. Agricultural Science Digest, 35 (2): 152-154.

\section{How to cite this article:}

Premraj Gocher, A.K. Soni, Arun Kumar Mahawar, S.P. Singh and Sunita Koodi. 2017. Response of NPK and Sulphur on Nutrient Analysis and quality attributes of Cauliflower (Brassica oleracea var. botrytis L.). Int.J.Curr.Microbiol.App.Sci. 6(7): 4364-4371. doi: https://doi.org/10.20546/ijcmas.2017.607.454 